\title{
Revision of the 1844 Palestrina earthquake following the recovery of an unpublished document
}

\author{
Andrea Tertulliani, Sergio Del Mese, Rita Di Giovambattista and Mario Pirro \\ Istituto Nazionale di Geofisica, Roma, Italy
}

\begin{abstract}
The paper presented originates from the recovery of an unpublished document that reports estimated damage in the city of Palestrina (Central Italy) following the 1844 earthquake. This document is not quoted in the sources and repertoires concerning earthquakes in the Palestrina area, and it has probably never before been used in studies for seismic hazard evaluation. Analysis of the document has allowed us to state the distribution and severity of damage due to the seismic event, assessing an intensity of VII MCS for Palestrina. Comparison with other coeval documents evidenced a possible lack of information with respect to the dwellings of the less well-to-do population, granting the hypothesis of a more serious damage level. The distribution of effects within the town centre of Palestrina has been compared with the surficial geology, evidencing a strong dependence of the seismic response on the local geomorphology. Such results are also confirmed by a similar damage pattern following the 1876 earthquake, and allow us to outline a realistic view of Palestrina's seismic vulnerability.
\end{abstract}

Key words historical research - Palestrina - site effects - intensity

\section{Introduction}

The town of Palestrina is situated approximately $30 \mathrm{~km}$ east of Rome, near the quaternary volcanic district of Colli Albani (fig. 1). Analysis of the seismic catalogues shows that Palestrina has suffered large earthquakes from the Apennines chain (up to intensity VII for the 1915 Avezzano event), moderate earthquakes from the Colli Albani system and, low local seismicity. To date, seismological research has been unable to classify the different seismogenic areas of the region accurately,

Mailing address: Dr. Andrea Tertulliani, Istituto Nazionale di Geofisica, Via di Vigna Murata 605, 00143 Roma, Italy; e-mail: tertul@ing750.ingrm.it with the exception of the Colli Albani district. A better understanding of the seismicity of this area can be realized by way of a complete interpretation of minor events - an important requisite for characterizing the seismic hazards of the Latium Tyrrhenian margin.

The Colli Albani district is the most active seismic zone in the neighbourhood of the study area where the ING seismic catalogue quotes more than 3000 earthquakes during the period from 1700 to 1975 . With a maximum intensity of VIII MCS, the seismicity has been predominantly clustered on the western side of the volcano. The largest Colli Albani earthquakes (i.e. 1806, VIII MCS and 1899, VII MCS) produced intensity VI effects in Palestrina (Molin, 1981; Camassi and Stucchi, 1997).

The importance of low seismic activity located near Rome, has recently motivated several publications investigating regional seismic hazards (see Molin et al., 1995). The moderate 


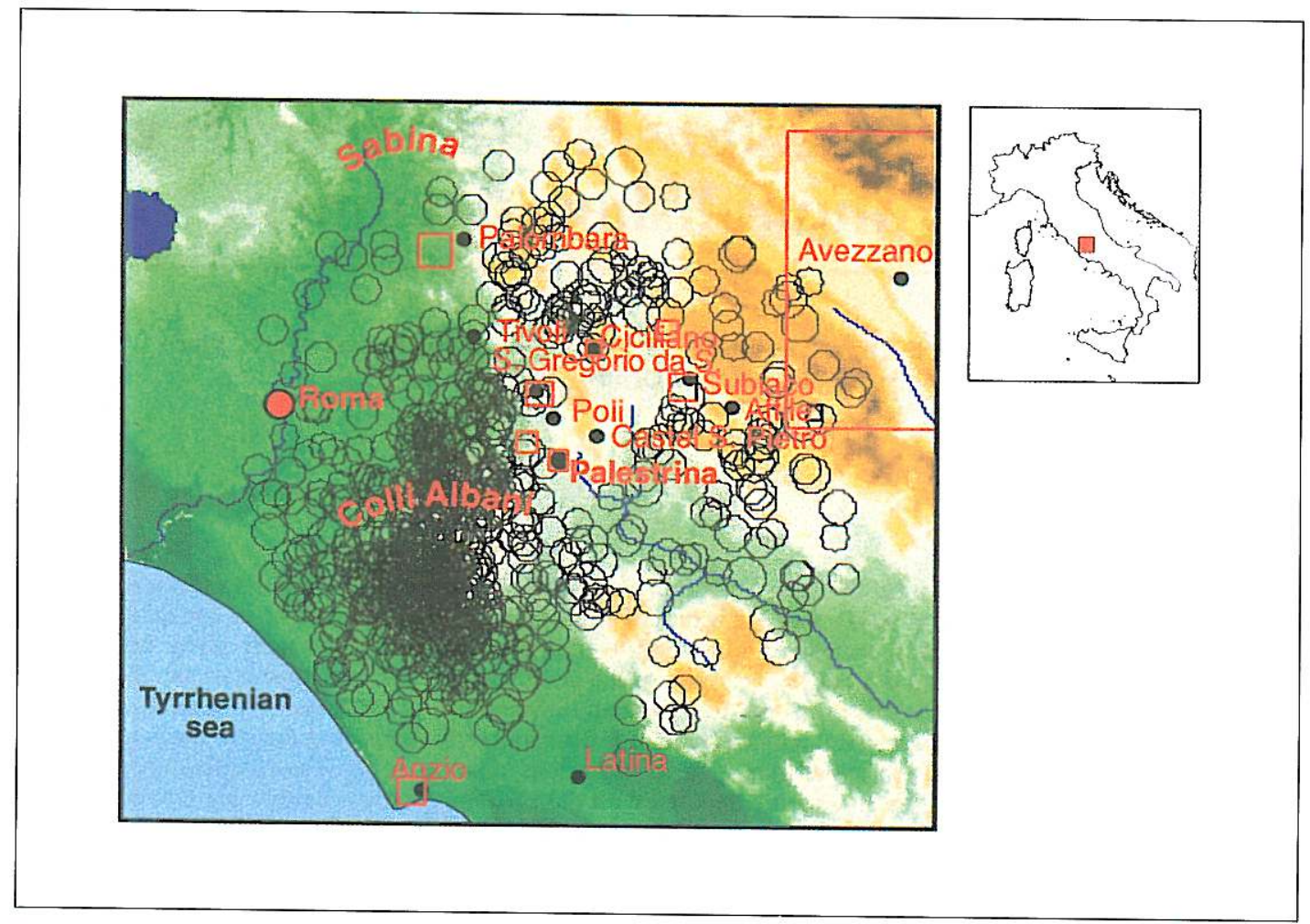

Fig. 1. Seismicity of the region as inferred from the ING catalogue (ING, 1996). The historical earthquakes quoted in CFT and NT4 are shown in squares.

seismicity of the Tyrrhenian margin had not encouraged a large number of studies to clarify the ambiguous events exhibited in the catalogues. However, the recovery of an unpublished document relating to the Palestrina 1844 event, is the foundation on which research on the seismic risk in that area has been based.

\section{Geological sketch}

The historical centre of Palestrina (fig. 3) is settled on the southern slopes of the Prenestini Mountains (Latium, Central Italy), a mountainous chain situated between the Colli Albani volcanic district to the west and the Central Apennines to the east. From a structural point of view, the Prenestini mountain ridge is a NS striking thrust belt of the Sabina sequence, a transition series showing the joint characteristics between pelagic units of the UmbroMarche sequence and the carbonate platform structure of the Laziale-Abruzzese sequence. The area is characterized solely in Cenozoic terms which outcrop as limestones, marly limestones and marls embedded with calcareous debris. Recently, the West Latium Tyrrhenian margin of the Apennines, from the Sabina to the Pontina plain, was identified as a discontinuous shear zone (Faccenna, 1994), where superficial elements indicate renewed activity of pre-existing buried structures (fig. 2). Inadequately investigated prior to this date, historical earthquakes located along this shear zone are probably linked to the current dynamics of the region. 


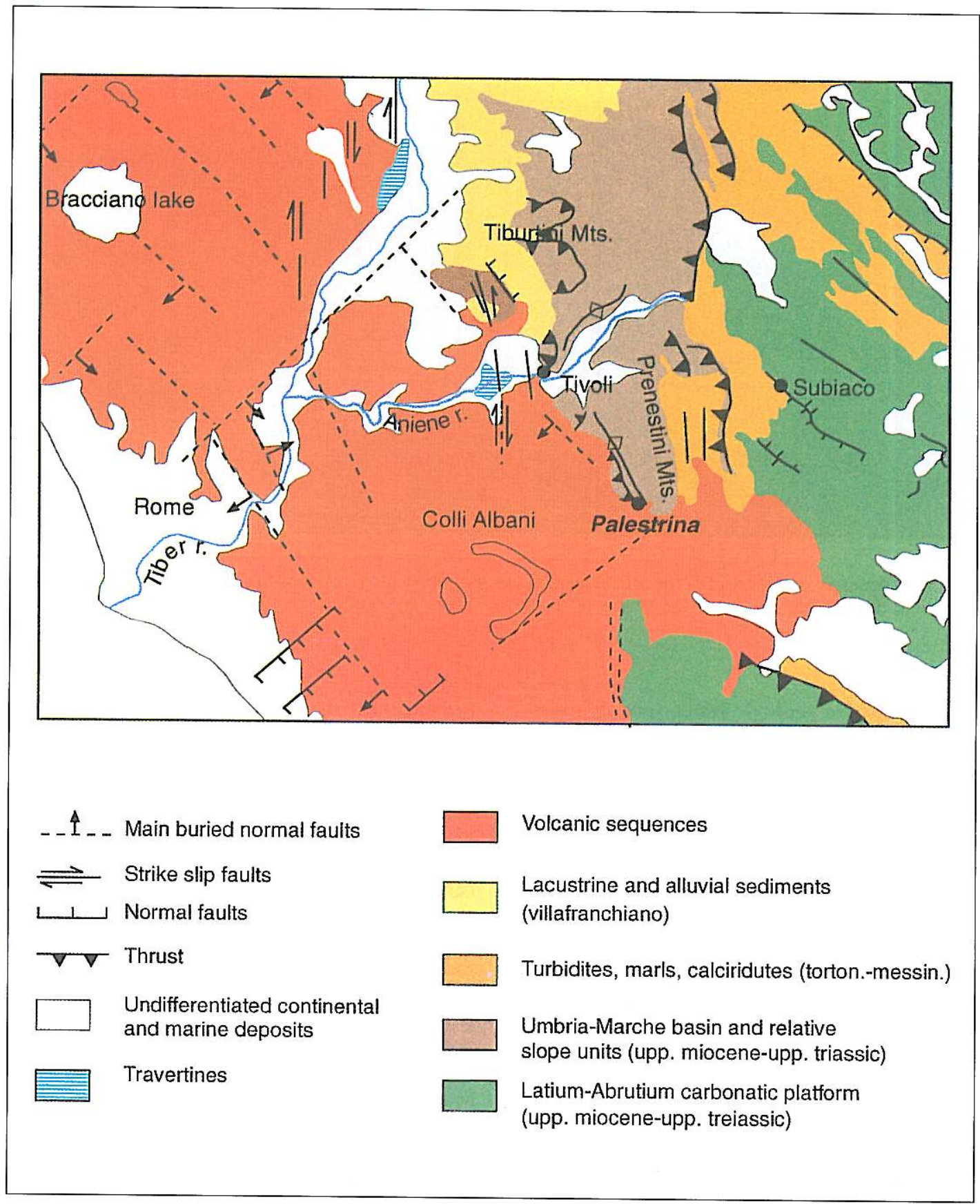

Fig. 2. Geological sketch of the Tyrrhenian margin of the Central Apennines. Redrawn after Corrado and Montone (1994); Faccenna (1994). 


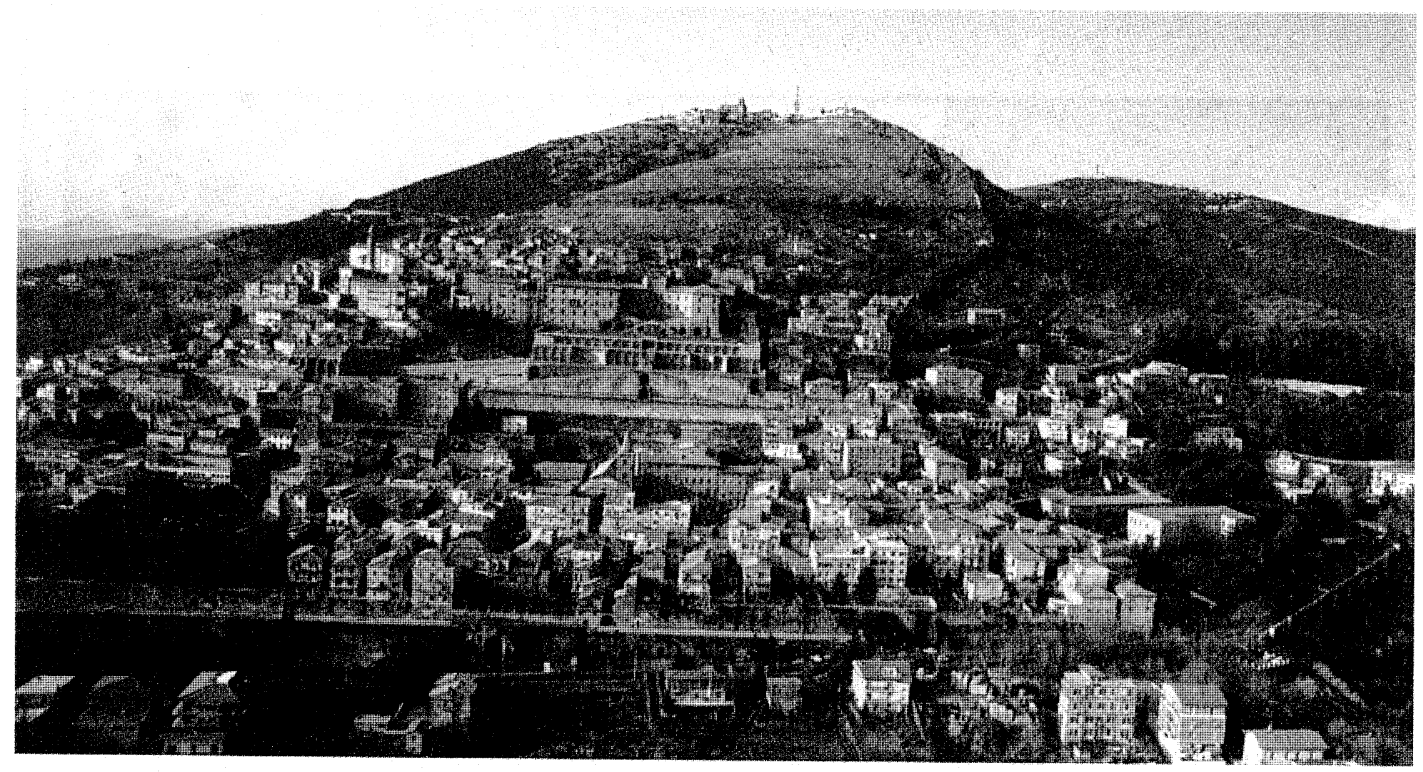

Fig. 3. Landscape of Palestrina's historical centre, on the slope of Mt. Ginestro. The ruins of the Fortuna Primigenia temple are visible in the centre of the town (photo by courtesy of Renato Funiciello).

A conclusive geologic frame, giving a seismic interpretation of the Palestrina historical centre, has been drawn from a series of geological and stratigraphical investigations performed in urban Palestrina and the surrounding area.

Evaluation of bore samples made during water exploration tests in Palestrina, determined the depth of the anthropic embankment and recent formations (pyroclastic deposits and alluvial sediments) from some metres to a few tens of metres, followed by around $30 \mathrm{~m}$ of calcareous debris of variable grain size, superimposed onto the marine blue clays of the PlioPleistocene.

As a result of these studies, the geology of the urban centre of Palestrina can be divided into two zones which are characterized by dissimilar topography and lithology and are separated by a normal fault that cuts the inhabited area in an $\mathrm{E}-\mathrm{W}$ direction.

The area set above the main street (from approximately $450 \mathrm{~m}$ above sea level) (fig. 4), is located on a strong upward incline, with outcropping of Cenozoic calcareous and siliceous material; the zone set in the valley below the main street is based on artificial terraces initiating from the pre-Roman epoch to the present day. The thickness of the anthropic embankment, essentially constituted by reworked vulcanites, differs from place to place with maximum values of around 10 to $15 \mathrm{~m}$.

The inclination of the slope directly below the fault footwall is very low, almost subplane. Beneath the anthropic embankment, there is an interesting thickness of pyroclastic material from the nearby Colli Albani volcanic district. Such material appears as an alternation of scoriaceous or lithified tuff, intercalated with debris of nappe fall down from the ridge and consisting of calcareous material in a red residual matrix (cyan area in fig. 8). The presence of this heterogeneous terrain, whose geotechnic quality is different from the bedrock, can play an important role in the seismic response of the city. 


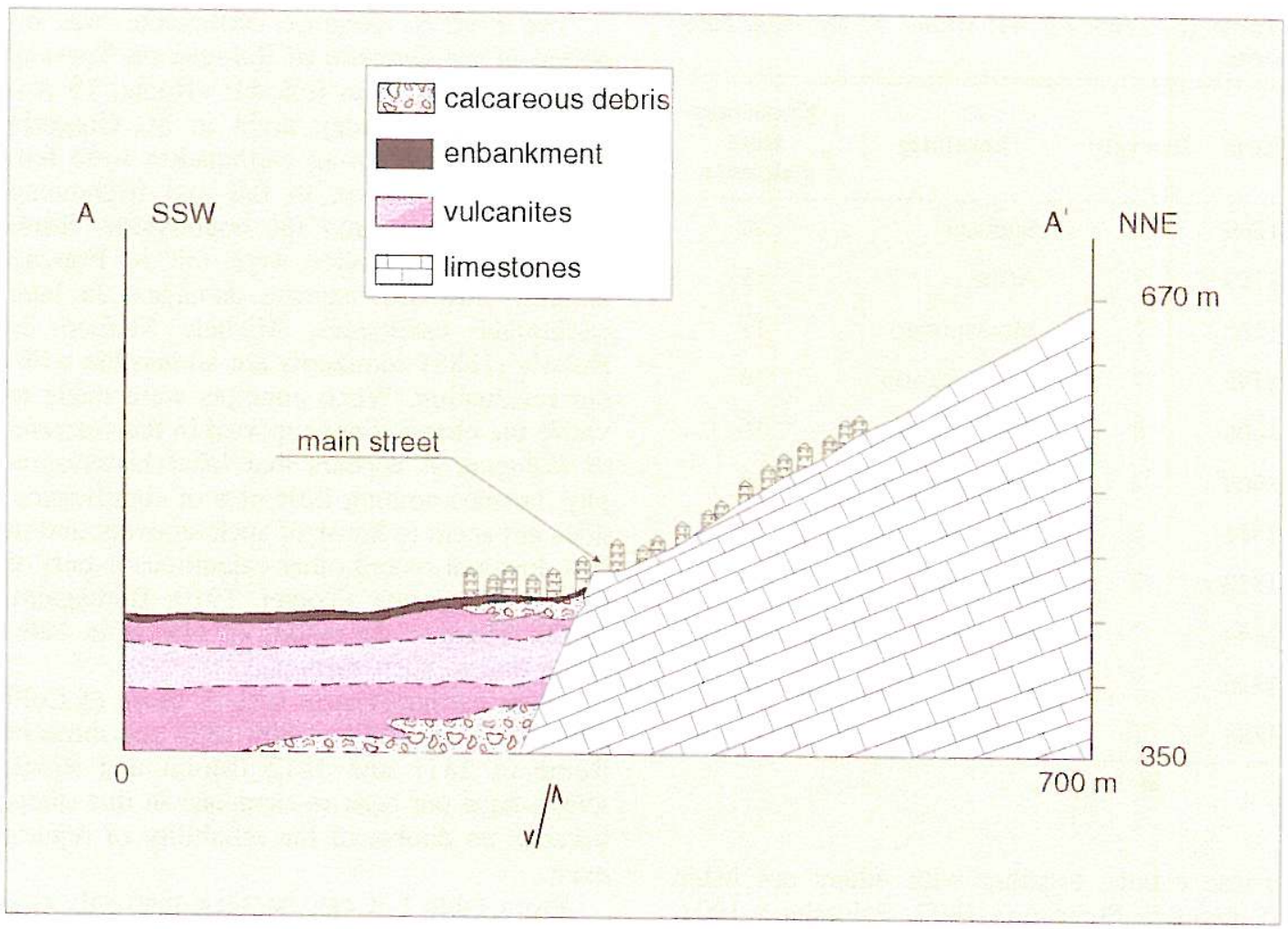

Fig. 4. Geological section of the urban Palestrina area. The main street is indicated by the arrow.

\section{Historical and instrumental seismicity of Palestrina}

The previous sections together with analysis of fig. 1, reveal the difficulties involved in differentiating seismogenic areas within the Latium-Tyrrhenic border, whose seismicity appears to be virtually continuous from Palestrina to Rome.

From an analysis of the distribution of the instrumental seismicity, it is possible to observe that some epicentres are located in the easternmost sector of the Colli Albani bordering the territory of Palestrina. When taking the distribution of seismic stations into consideration, it should be noted that events of small magnitude occurring in this area could be inaccurately located due to the poor azimuthal cov- erage of the national seismic network (Barba et al., 1995).

An extraction of events with an intensity equal to, or greater than the VII degree and occurring within a $20 \mathrm{~km}$ radius centred in Palestrina, was performed on the seismic catalogue of the Istituto Nazionale di Geofisica (ING) (1450 A.C.-1996) (ING, 1996). From these data it is possible to see that the study area has attracted a moderate level of seismicity. In the catalogue, only eleven earthquakes are quoted.

The historical investigation revealed some of the earthquakes listed in table I to be documented by rather doubtful sources. For three of them, Subiaco 1299, Affile 1759, San Gregorio 1795 , recent research with the addition of new elements, has not improved their reliability. 
Table I. Events $I \geq$ VII within $20 \mathrm{~km}$ from Palestrina.

\begin{tabular}{cclc}
\hline \hline Year & Intensity & Localities & $\begin{array}{c}\text { Kilometers } \\
\text { from } \\
\text { Palestrina }\end{array}$ \\
\hline 1299 & $7-8$ & Subiaco & 20 \\
1759 & 7 & Affile & 18 \\
1782 & 7 & Monteporzio & 17 \\
1795 & 7 & San Gregorio & 10 \\
1806 & 8 & Colli Albani & 16 \\
1809 & 7 & Montecompatri & 16 \\
1811 & 7 & Roma area & 13 \\
1812 & 7 & Roma area & 13 \\
1844 & 7 & Palestrina & 0 \\
1876 & 7 & Palestrina & 0 \\
1883 & 7 & Colli Albani & 18 \\
\hline
\end{tabular}

These events, together with others not listed (Capranica Prenestina 1897, Palombara 1901, San Vittorino 1904 and 1995, Ciciliano 1915, Tivoli, 1997) occurred in a band delimited by the depression hosting the Colli Albani and the western border of the Apenninic chain.

Another common characteristic seems to be the incompleteness of sources that are the origin of subsequent interpretations of these earthquakes. For example, the 1299 Subiaco event may have been confused with the 1298 Rieti earthquake which occurred exactly one year before (Molin, 1995; Di Giovambattista et al., 1997). In the most recent revision of historical earthquakes «The Catalogue of Strong Earthquakes in Italy from 461 B.C. to 1990» (Boschi et al., 1997), such events have been overlooked.

The 1759 Affile earthquake is reported by Jannuccelli (1856), based on documents existing in the Affile parish archive which concern a miraculous circumstance related to the end of the earthquake. Other investigations have not revealed information sufficiently interesting to encourage revaluation of this event.
The 1795 S. Gregorio earthquake, was reported in the Gazzetta di Bologna on Tuesday August 25th 1795 as follows: «Rome, $19 \mathrm{Au}-$ gust. During Saturday night in St. Gregorio near Tivoli, two strong earthquakes were felt, causing three houses to fall and frightening those inhabitants into the countryside. Similarly the same shakes were felt in Frascati without, however, causing damage». In later earthquake catalogues, Michele Stefano de Rossi's (1889) comments are admissible without revaluation. When attempts were made to verify the observations reported in the Gazzetta di Bologna, it appears that local historiography, besides nothing little else of significance, does not seem to know of such an event and in fact does not record other calamitous events of the XVIII century (Tomei, 1910; Barbagallo, 1982). There is no record of effects in Palestrina due to such earthquakes.

Other earthquakes in table I, those of Colli Albani of 1782, 1806, 18091883 and those of Rome of 1811 and 1812 (Molin and Rossi, 1994), have not been re-examined in this study, because no doubts of the reliability of reports exist.

From table I it can be seen that only two events, those of 1844 and of 1876, had the macroseismic epicentre in Palestrina. Such earthquakes ( $I=$ VII MCS), together with the intensity due to the Avezzano 1915 earthquake, represent the maximum felt intensity in the city. The event of July 17, 1844 was preceded by some premonitory tremors of low strength during the previous month, while that of 1876 was followed by eleven aftershocks of an intensity varying between the III to $\mathrm{V}$ degree. Despite the relative recent occurrence of these events, to date only correspondence or newspaper reports have been available, with no administrative or government sources found. The sources quoted in the seismic catalogues belong to the seismological repertoire of the XIX century.

Concerning the 1844 Palestrina earthquake, Baratta (1897) compiled information from the Gazzetta Piemontese of August 8th 1844, which was the only coeval source used. Conversely, the 1876 earthquake is described by De Rossi (1877), using information collected from per- 
Table II. The 1844 earthquake in the catalogues.

\begin{tabular}{lccl}
\hline \hline \multicolumn{1}{c}{ Catalogue } & Intensity & Epicentre & Locality \\
\hline ING (ING, 1996) & VII & $41.883-12.917$ & Palestrina \\
PFG (Postpischl, 1985) & VII & $41.833-12.916$ & Valmontone \\
NT4.1 (Camassi and Stucchi, 1997) & VI-VII & $41.839-12.891$ & Palestrina \\
\hline
\end{tabular}

sonal correspondents at the site. Later research has done little other to confirm these as being the only sources available.

Table II summarizes the records reported in the catalogues with respect to the 1844 earthquake.

\section{The July 17, 1844 earthquake in the unpublished document}

The discovery of an original document (ASR, 1844) that records the evaluation of damage suffered at Palestrina on the occasion of the earthquakes on July 14 and 17, 1844, motivated the study. It concerns an inspection performed by the Head Ledger Mason A. Ferracci, under order of the Magistracy (fig. 5). Dated August 5, 1844, the damage evaluation encompassed around 50 buildings within the town of Palestrina. The inspection by Ferracci is an accurate examination, house by house, with the noting of damage being made in relation to the condition of the buildings, to determine the expense for repairs. To identify ownership of the damaged buildings with regard to their location in the urban plan of Palestrina, we used the «State of the Souls» parish records of the S. Agapito Cathedral and the Gregorian Cadastre of 1819 (fig. 6).

From an accurate reading of the inspection of Ferracci and the Gregorian Cadastre of Palestrina, it becomes evident that the buildings visited for the evaluation of damage belonged to either noble families or to families near to local power - identifiable by the Barberini code or the Roman Church. Ferracci's evaluation completely omits any information regard- ing the poorer class of Palestrina dwellings and particularly any account of the «Scacciato» quarters, where historically the less well-to-do population resided. For social and political reasons, it appears the humble population did not have access to administrative channels for documentation and compensation. The cause of such incompleteness can therefore largely be credited to the political management of grants by local notables, together with the cultural backwardness of this less privileged sector of the population. In this case, as is sometimes detected in the study of historical events, such incompleteness can lead to an underestimation of the effects of the earthquake; in fact, it is reasonable to assume that the common dwellings had suffered damage at least comparable to that reported in the rest of the town. The hypothesis of bias does not allow us to give a definitive evaluation of the actual damage in relation to the overall urban estates of Palestrina. Nevertheless, we consider it appropriate to use the data of the unpublished document, both to reassess the intensity of the earthquake by improving the reliability of other sources, and to delineate the distribution of the effects in the inhabited area with the objective to identify a possible preferential seismic response.

\subsection{Building types and historical influences}

The urban centre of Palestrina today traces the 1800 settlement and is conclusively influenced by the artificial terracing created during the Roman period on the slopes of Mt. Ginestro. Many times destroyed and rebuilt, Palestrina exhibits obvious construction style over- 


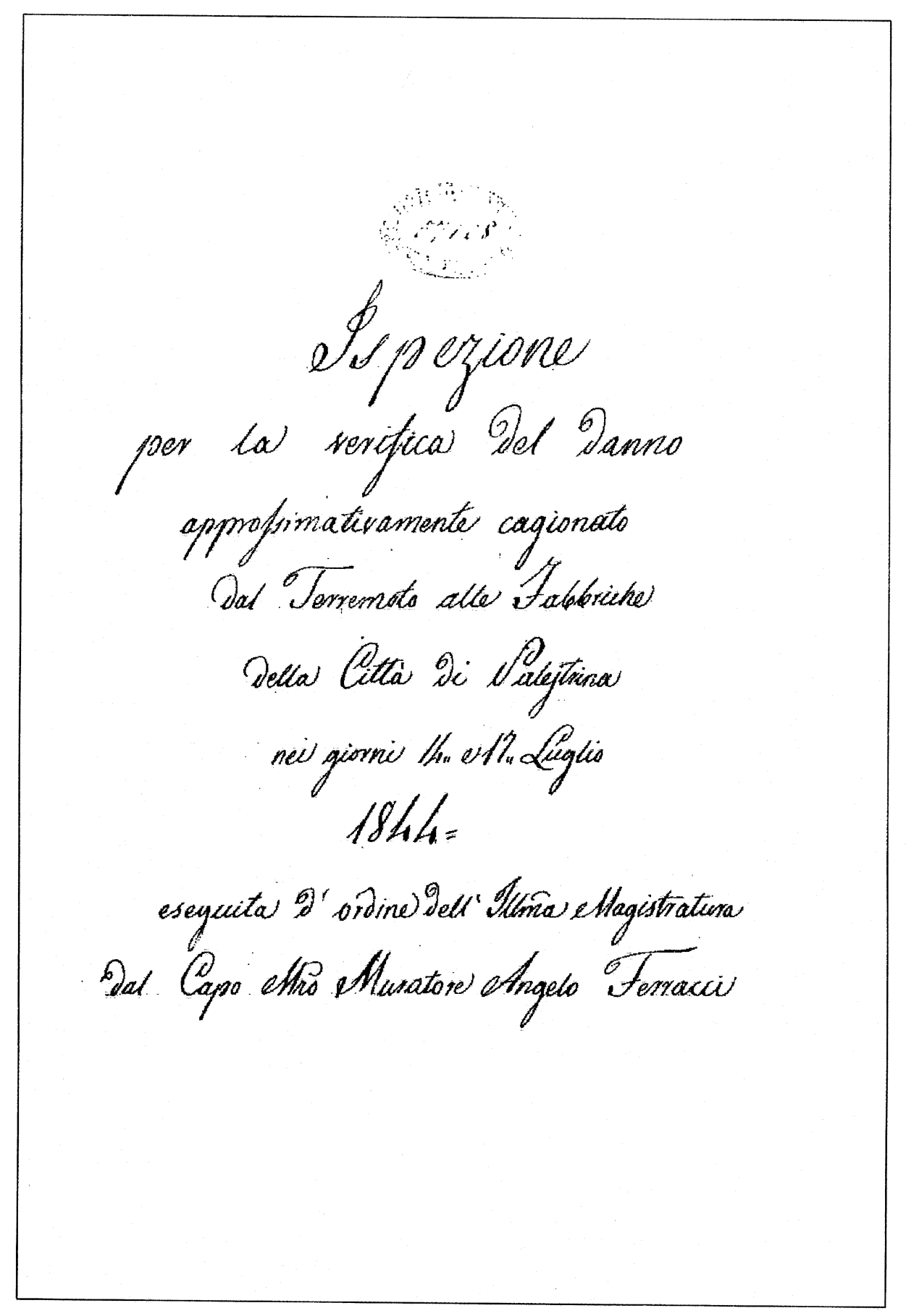

Fig. 5. Frontispiece of the Report by A. Ferracci (ASR, 1844). 


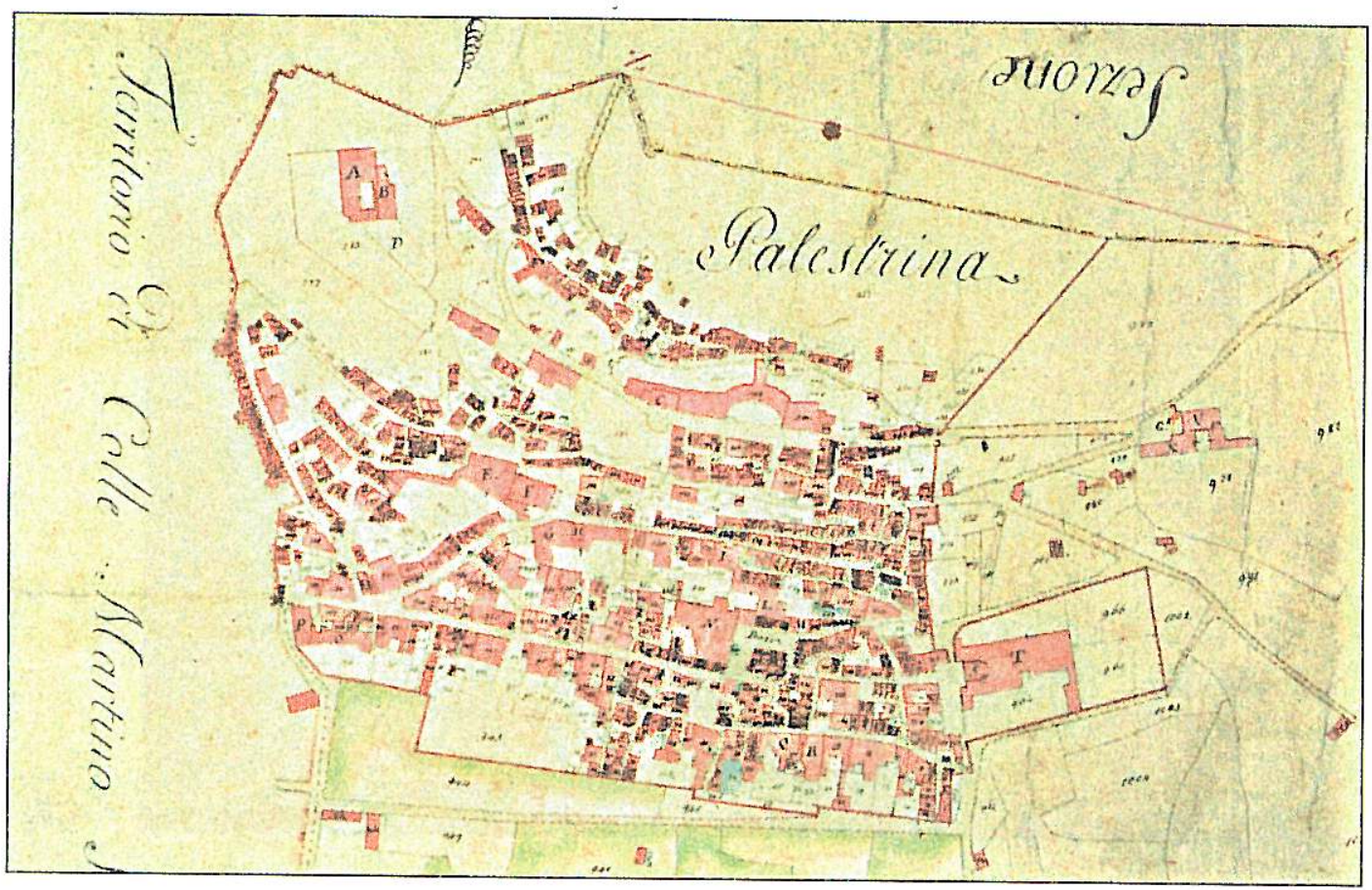

Fig. 6. Photograph of the original picture of the cadastrial map of Palestrina (ASR, 1819).

laps, shaped by the presence of the Fortuna Primigenia temple. The resulting layout is a typical arrangement of sub-parallel terraces, based on the Roman ruins and connected by stairways among levels.

Construction materials used are essentially the limestone, extremely widespread in the Prenestine area, and the tuff, obtained from the volcanic district of the Colli Albani. These materials have often been used in a heterogeneous way, together with pieces taken from the dismantled Roman temple which are sometimes used for ornament, structure, filling or as mortar stone (fig. 7a,b).

Detailed standards have not been recovered to enable classification of the town's buildings in terms of vulnerability relative to the era of the earthquake. Nevertheless, on the basis of sources consulted, it is possible to propose a reliable classification by the following categories:
1) Houses in adobe masonry, built with rubble stone, frequently with flat arch openings and reed floors. Extremely poor mortars.

2) Houses in masonry with simple or squared stone, sometimes with tuff blocks coarsely worked, usually based on ancient structures and/or calcareous spurs.

3) Buildings in squared stone masonry, having corners of tuff, keystones, jambs and basements in limestone; floors and/or trusses in wood; usually based and/or bound on monumental foundations.

As in almost all small Italian centres, all three of these construction types would be categorized under vulnerability class A within the EM 92 scale (Grünthäl, 1993), while only the best buildings of the third category could be placed in class B. The vulnerability of each building is also determined by the structure and geometry of the block, together with the quality of workmanship. 
(a)

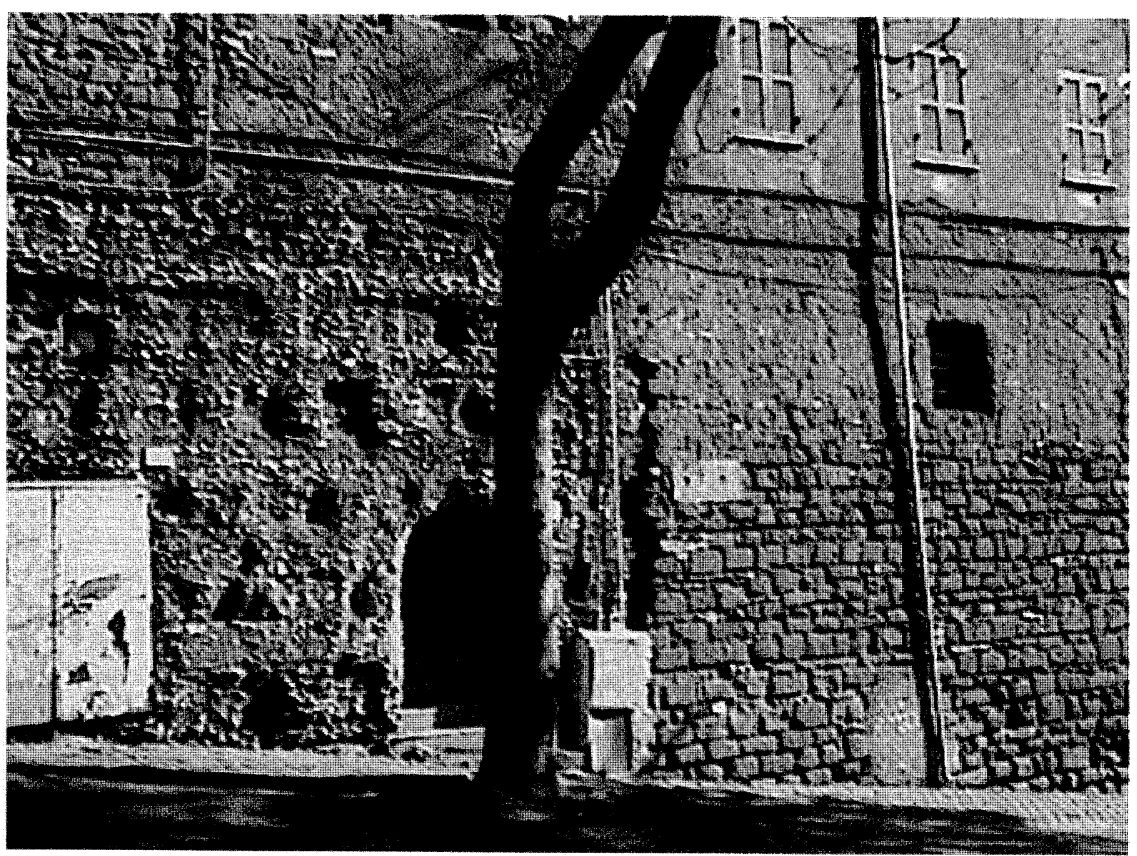

(b)

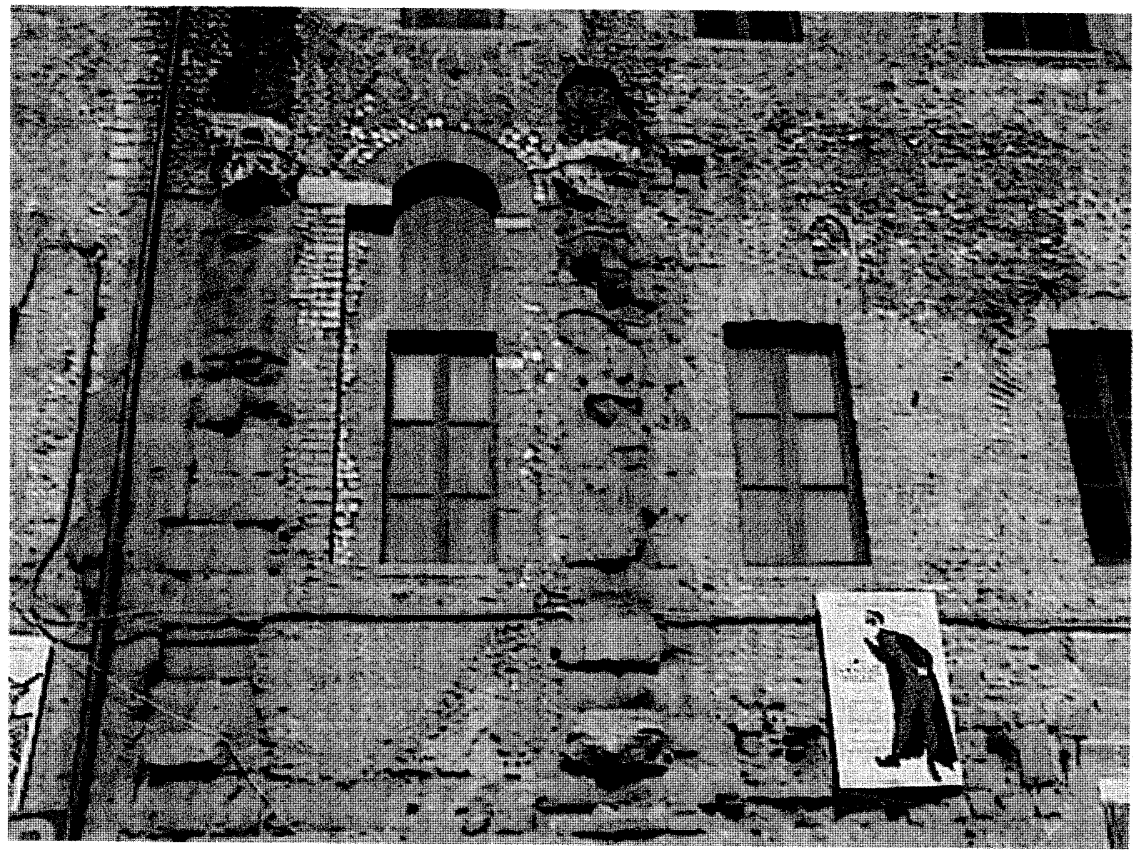

Fig. 7a,b. Photographs illustrating some characteristics of the building types in Palestrina. Evidence of construction style overlapped from Roman to later eras, using different materials. 
Table III. Categories of damage.

\begin{tabular}{lcccc}
\hline \hline & $\begin{array}{c}\text { Negligible } \\
\text { to moderate }\end{array}$ & Remarkable to heavy & Very heavy \\
\hline Class of damage & 2 & $2-3$ & 3 & $3-4$ \\
Monumental buildings & Many & Many & Many & Very few \\
Ordinary buildings & Few & Few & Few & - \\
\hline
\end{tabular}

\subsection{Evaluation of the intensity}

From the comparison between the damage estimated by Ferracci after the earthquake (ASR, 1844) and the Gregorian Cadastre of 1819 (ASR, 1819), it is possible to conclude that the appraisal has been performed on around $10 \%$ of the dwellings in the historical centre. The same evaluation has been performed on approximately $70 \%$ of the monumental buildings. On these buildings the damage recorded varies from rare partial collapses, frequent wide cracks in the external walls, break-up of partitions and lintels and, in a few houses, widespread light cracks on the internal and external walls. It is evident from table III that the damage to the monumental buildings, churches and monasteries seems to be more serious, possibly due to their structural complexity. As already mentioned, no information is available with respect to the damage which occurred to the dwellings of the less well-to-do population (cat. 1), which were certainly vulnerable.

The data has been categorized according to severity of damage and type of construction, according to the above description and using the EM92 scale as a model (Grünthäl, 1993) (table III). Where the description did not allow assignment to a data class, an intermediate evaluation was made between this and the immediately inferior class.

The overall picture that emerges is that of some diffuse damage within the inhabited area of Palestrina, with only very few serious or very serious instances recorded. In those cases the intensity assessment suffers due to the uncertain determination of the vulnerability class of the building concerned. To highlight the kind of problems occurring in those cases, assignment of the macroseismic intensity was performed by way of two independent methods: through the EM92 scale (Grünthäl, 1993) and MCS scale. The latter according to the standard procedure in use at ING (Gasparini et al., 1992), that requires a class subdivision of vulnerability. This method was also selected to provide further elements of discussion with respect to difficulties encountered in the evaluation of intensity originating from historical documents (Monachesi and Moroni, 1993, 1995). We can affirm that the A and B classes of vulnerability within the EM92 scale are compatible with those described in the ING procedure (Tertulliani, 1995), and are therefore interchangeable with respect to the goals of the evaluation of intensity by both methods. As discussed, construction types evident in Palestrina during the period of the earthquake, belong to the classes of vulnerability $\mathrm{A}$ and $\mathrm{B}$, and without further details on the distribution of such buildings, we hypothesized the occurrence of damage to all structures A (least hypothesis) or B (maximum hypothesis) excluding the monumental buildings (Grünthäl, 1993) that serve as complementary elements to the evaluation.

Results of the intensity estimation are shown in table IV. It is necessary to repeat that this

Table IV. Intensity assessment results.

\begin{tabular}{ccc}
\hline \hline & EMS & ING questionnaires \\
\hline Total A & VI-VII & VII \\
Total B & VII & VII-VIII \\
\hline
\end{tabular}


may represent an underestimation, both due to the already described incompleteness of information and also because it is necessary to consider the generalized damage to the monumental structures and other buildings in the surrounding countryside.

In attempting to compile an eventual macroseismic field, investigation of the quake's effects in the neighbouring villages has not granted decided results as, following research of both community and private archives, no documents were recovered for Castel S. Pietro, Poli and other centres located around Palestrina. Marginal reports were found in two newspapers of the time: Il Giornale delle Due Sicilie and Il Diario di Roma. This absence of news relative to remarkable effects in surrounding areas makes reasonable the hypothesis of site seismic amplification of an earth- quake of moderate magnitude, which was limited to a part of Palestrina.

\subsection{Distribution of the effects}

A picture of the distribution of the effects in the urban territory of Palestrina is derived from a comparison with the cadastral map related in time to the event; the Gregorian Cadastre of 1819 (ASR, 1819). Thanks to the detail of the Ferracci evaluation, we located all the damaged edifices, highlighting how they were mostly clustered in the lower part of the historical centre of Palestrina (fig. 8). Serious damage was also recorded in other zones of the city, but mostly on monumental buildings. An isolated building like the S. Francesco monastery (in red in fig. 8), showed very heavy dam-

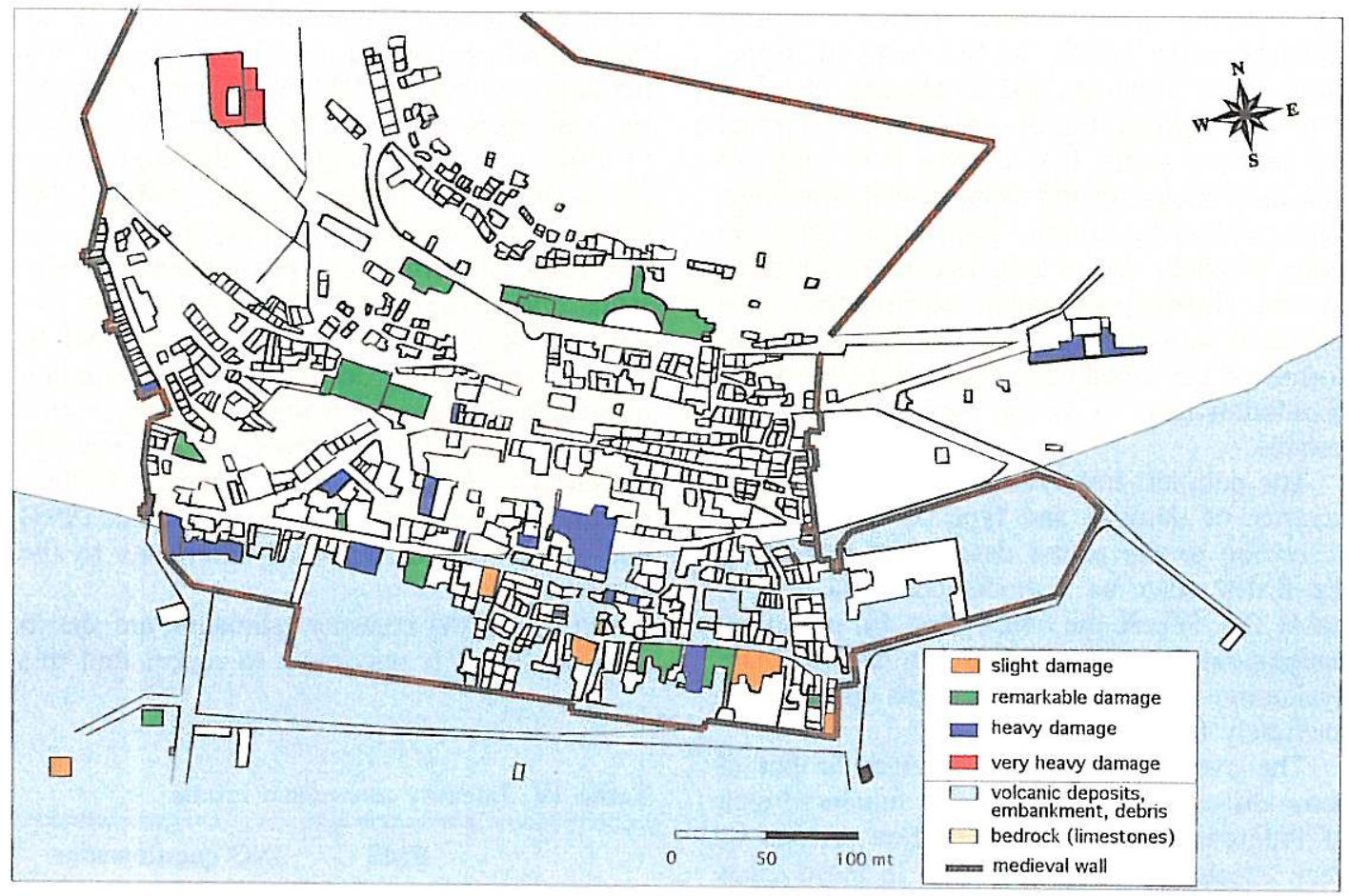

Fig. 8. Distribution of effects in the Palestrina urban map related in time to the event. The map has been redrawn from the original cadastrial map shown in fig. 6. 
age; this edifice was built on a sharp slope of the hill, outside the Roman area of Palestrina. In this case a topographic effect could be invoked to justify such damage.

It is interesting to compare this distribution of damage with that which occurred during the earthquake of October 26th 1876, as recorded by De Rossi (1877). Even though this latter evaluation is not so detailed, it is enough to show that the area which suffered the greatest amount of damage, was the same lower part of the city: "The houses in downtown Palestrina, some more, some less, have been rather ruined.... Of one hundred houses in the lower district, we do not find 10 that we can say are healthy» (De Rossi, 1877). As discussed in Section 2, there exists a clear geomorphological distinction between the zones below and above the main street, determined both from a clean division of the slope, and from a lithological point of view. The damage distribution seems to support this differentiation between the two zones, the downtown area being built on variations of anthropic embankments, debris, pyroclastic deposits and alluvial sediments, with lateral heterogeneities. Whereas, the uphill area, where little damage resulted, is built directly on a calcareous sharp slope. Amplification of the seismic response is possible where there are, as in the case of Palestrina, areas with a great contrast of impedance caused by the contact between different rocks ( $\mathrm{Su}$ et al., 1992; Rovelli et al., 1994; Funiciello et al., 1995). Direct observations of recent Italian earthquakes also confirm how often the surface geology is decisive in driving the damage pattern (Mucciarelli et al., 1997; Tertulliani and Maramai, 1998). Very recent instrumental observations have evidenced a strong generation of surface waves by diffraction at the rock edge of a basin, see also fig. 4. It is possible in this way to explain abrupt variations in the severity of damage between neighbouring buildings of similar construction.

\section{Conclusions}

The recovery of a coeval document regarding the damage produced by the 1844 Pale- strina earthquake, provided an opportunity to deepen the study of this event and, in general, has allowed us to deal with the seismicity of the whole area. The difficulty in studying this area, characterized by low seismicity and monitored by a few seismic stations, is mainly due to a defect of data. This problem becomes evident when attempting to determine the different seismogenic areas of the Roman region. Instrumental seismicity, limited both in quality and in quantity, overlaps with that of the Colli Albani district and does not yield a clear delineation of the seismogenic zones. The integration of historical seismology therefore plays an important role in the revision and enhancement of instrumental data. With the improvement of seismic monitoring, the absence of relevant seismicity in the area of Palestrina is an element which should not be neglected when evaluating the seismic hazards of the zone. Consideration should also be given to the other doubtful or little studied earthquakes occurring in the western margin of the Apennines and Latium. In this context, the recovery of a coeval document on the earthquake of 1844 demands deeper examination.

The importance of the new source is remarkable for at least two aspects; firstly for its contribution to the seismicity knowledge of Palestrina and the surrounding areas, which in turn granted redefinition of some of the earthquake's parameters as quoted in the records of the seismic catalogues; secondly, as a new source for the study of local seismic response and the seismic vulnerability of the site.

In expanding this first aspect, some specific features linked to the interpretation of historical sources arise following the comparative reading of Ferracci's evaluation and the Gregorian Cadastre, together with other coeval documents of a historical and administrative type. The fact that the buildings recorded as damaged nearly all belonged to the local notables, while the description of damage to the poorer buildings is absent, opens a believable hypothesis of the incompleteness of the scene of damage. This is consistent with an evaluation of macroseismic intensity of a VII degree MCS, or a VI-VII EM92, also more than likely underestimated for the same reasons. Neverthe- 
less, these values of intensity also confirm those present in the catalogues and are based on a reliable coeval source.

The second aspect concerns the distribution of the effects in the historical centre of Palestrina, for the purpose of revealing a possible amplification of the seismic response. With the damaged buildings being to the greatest extent clustered in the historical centre of Palestrina (fig. 8), and particularly beneath the footwall of the fault, dissection of the damage and damage distribution in relation to the surface geology has shown some interesting results. The analysis has produced a marked division of the slope that coincides with where the limestone bedrock comes into contact with terrain constituted by alternations of anthropic embankments, vulcanites and alluvial sediments. The damage is greater in buildings constructed on this last terrain, confirming the existence of a contribution of the surface geology to the effects pattern. In particular, we recognized the role of an «edge-effect», due to the contact between hard-rock and softer sediments, acting as diffracting structures. This observation, further confirmed by the similar distribution of damage occurring in the same zone during the 1876 earthquake, seems to reveal an area of Palestrina that is more vulnerable to seismic shaking.

\section{Acknowledgements}

Our thanks go to G. Tomassi of Palestrina for his contribution to the retrieval of decisive information for the location of buildings damaged by 1844 earthquake, and for his valuable suggestions during the study. We are grateful to L. Bandiera and to N. Zattini of Palestrina for their help; we also thank Z. Zanardi of IBC, Bologna, G. Giacobello of Biblioteca Reale of Turin, Dr. A. Tomei and A. Petrini for their contribution to historical researches. M. Vecchi and A. Felici are also thanked, for putting their own experience in respect of the damage evaluation at our disposal and A. Massucci for having contributed with patience to the graphic realization of the work. R. Funiciello provided valuable comments. S. Watt is acknowledged for the revision of the English text.

\section{REFERENCES}

ASR (Archivio di Stato di Roma) (1819): Catasto Gregoriano, Camarca 157, Presidenza del Censo, Mappa originale del territorio della Comunità di Palestrina sez. I.

ASR (Archivio di Stato di Roma) (1844): Min. Int., tit. 36, busta 298 , Ispezione per la verifica del danno approssimativamente cagionato dal terremoto alle fabbriche della città di Palestrina nei giorni 14 e 17 luglio 1844, Palestrina.

BARAtTA, M. (1897): Materiali per un catalogo dei fenomeni sismici avvenuti in Italia (1800-1872), Mem. Soc. Geogr. It., 7.

Barba, S., R. Di Giovambattista and G. Smriglio (1995): The ING Seismic Network Databank (ISND) a friendly parameters and waveform database, Ann. Geofis., 38 (2), 213-219.

Barbagallo, I. (1982): San Gregorio da Sassola dall'antichità ai nostri giorni, S. Gregorio da Sassola (Roma).

Boschi, E., E. Guidoboni, G. Ferrari, G. VAlensise and P. GASPERINI (Editors) (1997): Catalogo dei Forti Terremoti in Italia dal 461 a.C. al 1990 (ING, Roma SGA, Bologna), pp. 644.

CAMASsi, R. and M. STUCCHI (Editors) (1997): NT4.1 - Un Catalogo Parametrico di Area Italiana al di Sopra della Soglia del Danno, CNR-GNDT, Milano.

Corrado, S. and P. Montone (1994): Attitude data, lineaments and deformational styles of carbonate platform and slope domains in the Central Apennines, Mem. Soc. Geol. It., 48, 561-571.

DE Rossi, M.S. (1877): Quadri statistici topografici giornalieri dei terremoti avvenuti negli anni 1875-76 e segnatamente del massimo sismico prenestino del 26 ottobre 1876, Atti Accad. Pont. Naz. Lincei, 30, 121-127.

DE Rossi, M.S. (1889): Documenti raccolti dal defunto Conte Antonio Malvasia per la storia dei terremoti ed eruzioni vulcaniche massime in Italia, Mem. Pont. Accad. Nuovi Lincei, 5, 169-289.

Diario di Roma: 30/7/1844, Roma.

Di Giovambattista, R., A. Tertulliani and Z. Mari (1997): Doubtful events reported in current Italian Catalogues: the medieval earthquakes of Subiaco (Central Italy), Natural Hazards, 16, 39-55.

FACCENNA, C. (1994): Structural and hydrogeological features of Pleistocene shear zones in the area of Rome (Central Italy), Ann. Geofis. 37 (1), 121-133.

Funiciello, R., L. LOMBard, F. Marra and M. PAROTTO (1995): Seismic damage and geological heterogeneity in Rome's Colosseum area: are they related?, Ann. Geofis., 38 (5-6), 927-938.

Gasparini, C., V. De Rubeis and A. Tertulliani (1992): A method for the analysis of macroseismic questionnaires, Natural Hazards, 5, 169-177.

Gazzetta di Bologna: 25/8/1795, Bologna.

Gazzetta Piemontese: 178:2, VIII, 1844, Torino.

Giornale delle Due Sicilie: 18/7/1844, Napoli.

GRÜNTHÄL, G. (Editor) (1993): European Macroseismic Scale 1992, Cahiers du Centre Européen de Géodynamique et de Séismologie, 7, 79.

ING (1996): Italian Seismic Catalogue, Internal File Report. 
JANNUCCELli, G. (1856): Memorie di Subiaco e sua Badia Raccolte dal Canonico Jannuccelli, Cameriere d'Onore di Sua Santità, Custode della Prima Biblioteca Sublacense, Genova.

Molin, D. (1981): Sulla Sismicità Storica dei Colli Albani, CNEN, RT/AMB (81) 11, Roma

Molin, D. (1995): Revisione del catalogo dei terremoti, in Lazio Meridionale. Sintesi delle Ricerche Geologiche Multidisciplinari, edited by C. CARRARA, ENEA, Roma.

Molin, D. and A. Rossi (1994): Terremoto di Roma del 22 marzo 1812-studio macrosismico, in Atti del $12^{\circ}$ GNGTS, Rome, 279-286.

Molin, D., S. Castenetto, E. Di Loreto, E. Guidoboni, L. Liperi, B. NARCISI, A. PACIEllo, F. RiguzzI, A. Rossi, A. Tertulliani and G. Traina (1995): Sismicità di Roma, La Geologia di Roma: il Centro Storico, edited by R. FunicIELlo, Mem. Descr. della Carta Geol. d'Italia, Serv. Geol. Naz., 50, 353-356.

MonACHesi, G. and A. Moroni (1993): Problems in assessing macroseismic intensity from historical earthquake records, Terra Nova, 5, 463-466.

MONACHESI, G. and A. MORONI (1995): From historical earthquake records to intensity value: some results of a study, Ann. Geofis., 38 (5-6), 827-836.
Mucciarelli, M., G. Monachesi and L. Trojani (1997) Rilievo speditivo di funzioni di amplificazioni di sito in alcune località colpite dal terremoto del 26/09/1997, in Atti $16^{\circ}$ GNGTS, Roma (in print).

PostPISCHL, D. (Editor) (1985): Catalogo dei terremoti italiani dall'anno 1000 al 1980, Quad. Ric. Sci., CNRPFG, Bologna, 114.

Rovelli, A., A. Caserta, L. Malagnini and F. Marra (1994): Assessment of potential strong ground motions in the city of Rome, Ann. Geofis., 37 (6), 1745-1770.

Su, F., K. AKI, T. Teng, Y. Zeng, S. Koyanagi and K. MAYEDA (1992): The relation between site amplification factor and surficial geology in Central California, Bull. Seism. Soc. Am., 82, 580-602.

Tertulliani, A. (1995): Testing the European Macroseismic Scale (1992) (EMS92) on Italian earthquakes, Eur. Earthquake Eng., 2, 37-44.

Tertulliani, A. and A. MARAmai (1998): Macroseismic evidences and site effects for the Lunigiana (Italy) 1995 earthquake, J. Seism. (in print).

ToMEI, E. (1910): Memorie storiche di San Gregorio da Sassola, manuscript.

(received April 10, 1998; accepted September 1, 1998) 